\title{
T-Cell Surface Glycoprotein CD4 Staining Method
}

National Cancer Institute

\section{Source}

National Cancer Institute. T-Cell Surface Glycoprotein CD4 Staining Method. NCI

Thesaurus. Code C122851.

An immunohistochemical technique used to detect the presence of T-cell surface glycoprotein CD4 in a tissue sample. 